\title{
THE CHEMISTRY OF 2H-3,1-BENZOXAZINE-2,4(1H)-DIONE (ISATOIC ANHYDRIDE). 23 (1). SYNTHESIS OF 2-(2-PROPENYL)- AND 2-ISOPROPYLANILINES
}

\author{
Gary M. Coppola* and Craig M. Marsden \\ Department of Metabolic Diseases \\ Preclinical Research, Sandoz Research Institute \\ Sandoz Pharmaceuticals Corporation \\ Route 10, East Hanover, N.J. 07936
}

\begin{abstract}
Isatoic anhydrides react with excess methyllithium at $-78^{\circ} \mathrm{C}$ to produce tertiary alcohols 2 in high yields. The hydroxyl group of 2 can be dehydrated to give the 2-(2-propenyl)anilines 10 using iodine under azeotropic water removal conditions. Catalytic hydrogenation of the olefin affords the target 2 -isopropylaniline derivatives 11 .
\end{abstract}

\section{Introduction}

During the course of a recent project we required several 2-isopropylanilines as key synthetic intermediates. Since the commercial availability of ortho isopropylated anilines is limited to to 2-mono, 2,6-di, and 2,4,6-triisopropyl derivatives, other analogs with different functional groups and substitution patterns must be synthesized.

Few methods exist for the selective introduction of branched alkyl groups ortho to nitrogen in arylamines. The more successful approaches involve the alkylation of aniline with 2-propanol over zeolites (2) or with propene in the presence of homogeneous aluminum catalysts (3) or Lewis and Bronsted acids (4). These techniques, however, require rather harsh reaction conditions (600-1000 psi and $\left.250-330^{\circ} \mathrm{C}\right)$ which are not amenable to standard laboratory manipulations. Furthermore, in order to avoid polyalkylation, a large excess of aniline is required. Even under these conditions, $\mathrm{N}$-alkylation occurs as a major competing side reaction. Alternatively, 2 -isopropylanilines are available by $\mathrm{NiCl}_{2}$ (dppe)-catalyzed geminal dimethylation of dithioacetals (5) which are available from selective ortho-formylation of arylamines (6).

With these techniques the common motif of forming the aryl-isopropyl $\mathrm{C}-\mathrm{C}$ bond can be further complicated if the aniline carries functional groups which electronically disfavor aromatic substitution. The positioning of additional substituents on the aromatic ring (e.g. meta-substituted anilines) also presents the possibility of forming a mixture of 2,3- and 2,5-disubstituted alkylation products.

Rather than rely on a potentially capricious $\mathrm{C}-\mathrm{C}$ bond forming reaction to introduce the isopropyl group in the appropriate position, our strategy begins with starting materials where the desired bond between the aromatic ring and the central carbon of the isopropyl group is already established.

Isatoic anhydride 1 and its derivatives are ideally suited for this purpose. For nearly a century it has been recognized that the highly reactive $\mathrm{C}-4$ carbonyl of the of the benzoxazine heterocycle is extremely susceptible to nucleophilic attack by oxygen, sulfur, and nitrogen nucleophiles to give (after loss of $\mathrm{CO}_{2}$ ) 2-substituted anilines (7) (anthranilic esters, acids, thioesters, and amides). 
<smiles>O=c1[nH]c2ccccc2c(=O)o1</smiles><smiles>CC(C)[R]OC(=O)[O-]</smiles>

1

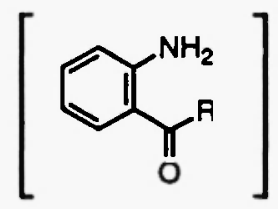

2<smiles>[R]C(C)(O)c1ccccc1N</smiles>

3

More recently, carbon nucleophiles have been explored. Lithium enolates of esters and ketones instantaneously add to isatoic anhydrides at $-78^{\circ} \mathrm{C}$ to give intermediates similar to $2\left(\mathrm{R}=\mathrm{CH}_{2} \mathrm{COOR}\right.$, $\mathrm{CH}_{2} \mathrm{COR}^{\prime}$ ) $(8,9)$. In these reactions, even though excess base (LDA) or enolate is used, the addition of the nucleophile to the carbonyl group stops after one equivalent is consumed. This is due to enolization of the resulting intermediate $\beta$-ketoester or $\beta$-diketone which insulates the carbonyl carbon from further nucleophilic attack. In the absence of the $\beta$-carbonyl $(2, R=$ alkyl) enolization is precluded thereby exposing the intermediate 2-ketoaniline 2 to further reaction with excess organolithium reagent, the consequence of which would produce 2 -aminobenzyl alcohol derivatives $\mathbf{3}$. Subsequent removal of the hydroxyl group would then result in the desired ortho-alkylated anilines.

\section{Results and Discussion}

Two of the four starting isatoic anhydrides $8 \mathrm{a}$ and $8 \mathrm{c}$ are commercially available. The remaining two were synthesized by oxidation of the appropriate substituted isatin derivatives (Scheme 1). The required isatins were prepared from anilines $\mathbf{\Psi}$ and $\mathbf{\underline { z }}$ by cyclization of intermediate isonitrosoacetanilides $(10,11)$.

\section{Scheme 1}<smiles>CC(C)c1ccccc1N</smiles>

4<smiles>Cc1c(N)cccc1Cl</smiles>

5
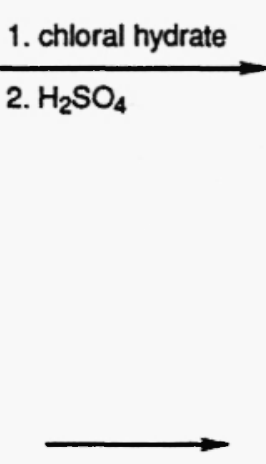<smiles>CC(C)c1cccc2c1NC(=O)C2=O</smiles>

6<smiles>Cc1c(Cl)ccc2c1NC(=O)C2=O</smiles>
7
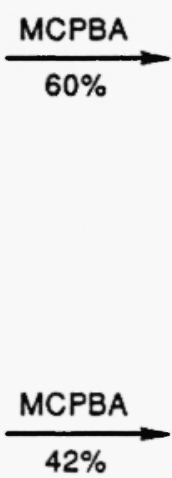

8d

Addition of the solid isatoic anhydride derivative 8 to 3.5 equivalents of methyllithium in THF at $-78^{\circ} \mathrm{C}$ results in vigorous evolution of carbon dioxide and formation of a yellow solution. After 5 minutes, the reaction was quenched with saturated ammonium chloride and the mixture was extracted into MTBE. The organic 
solution was dried over sodium sulfate and the solvent was removed to furnish essentially pure alcohol 2 in high yields (12). The products were usually carried on to the next step without further purification (Scheme 2).

Attempted dehydration of 2 met with mixed results. Heating 2 with $6 \mathrm{~N} \mathrm{HCl}$ at $110^{\circ} \mathrm{C}$ for 3 hours produced a mixture of two products. The major product was identified as the dealkylated aniline 12 . The minor product 10 was isolated in $<18 \%$ yield (e.g. 10c). The yield of desired product $10 \mathrm{c}$ could be increased to $46 \%$ by heating $2 \mathrm{c}$ with one equivalent of p-toluenesulfonic acid in benzene at $80^{\circ} \mathrm{C}$ for 7 hours, however, the yield could not be consistently reproduced. Heating $9 \mathrm{a}$ in acetic acid at $110^{\circ} \mathrm{C}$ for 30 minutes resulted in the formation of the acetoxy derivative 13 a (69\% yield).

\section{Scheme 2}<smiles>[R]c1ccc2c(=O)oc(=O)[nH]c2c1[R]</smiles>

8

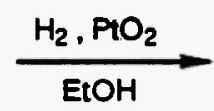

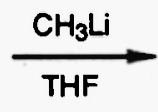<smiles>[R2]c1ccc(C(C)C)c(N)c1Br</smiles>

11<smiles>CC(C)(O)c1cc[14cH]c(Br)c1N</smiles>

9

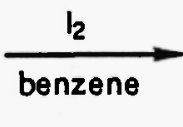

10<smiles>[R6]c1cccc(N)c1Br</smiles>

12<smiles>[R]c1ccc(C(=C)C)c(N)c1[R]</smiles><smiles>[R2]c1ccc(C(C)(C)OC(C)=O)c(N)c1[R]</smiles>

13

It was found that 2 could be reliably dehydrated to 10 using a catalytic amount of iodine in refluxing toluene under Dean-Stark conditions (13). The reaction is usually complete within 90 minutes. The olefin of 10 was easily reduced to $\mathbb{1}$ by catalytic reduction at one atmosphere over $\mathrm{PtO}$ in ethanol. The reaction was complete within one hour to produce the 2-isopropylaniline $\mathbb{1}$ in high yields (12) (Table 1).

If desired, intermediates 2 and 10 , which are oils, can be purified by flash chromatography, however, the anilines $\mathbf{1}$ are usually obtained in higher overall yield if the intermediates are carried on to the final products and purified at the end of the synthetic sequence.

Table 1. Yields of Compounds 10 and $\mathbf{1 1}$

\begin{tabular}{ccccc}
\hline 8 & $\mathrm{R}_{1}$ & $\mathrm{R}_{2}$ & Yield 10(\%) & Yield 11 (\%) \\
\hline a & $\mathrm{H}$ & $\mathrm{H}$ & 59 & 87 \\
b & $\mathrm{i}-\mathrm{C}_{3} \mathrm{H}_{7}$ & $\mathrm{H}$ & 56 & 95 \\
c & $\mathrm{H}$ & $\mathrm{Cl}$ & 81 & 84 \\
d & $\mathrm{CH}_{3}$ & $\mathrm{Cl}$ & 49 & 94 \\
\hline
\end{tabular}




\section{Keferences and Notes}

(1) Part 22: G.M. Coppola, J. Heterocyclic Chem. 29, 1873 (1992)

(2) R.B.C. Pillai and C.N. Pillai, Indian J. Chem, Sect B 32B, 592 (1993)

(3) G.G. Ecke, J.P. Napolitano, A.H. Filbey and A.J. Kolka, J. Org. Chem 22, 639 (1957)

(4) W.F. Burgoyne and D.D. Dixon, Applied Catalysis 63.117 (1990)

(5) Y. Tzeng, P. Yang, N. Mei, T. Yuan, C. Yu and T. Luh, J. Org. Chem 56, 5289 (1991)

(6) P.G. Gassman and H.R. Drewes, J. Am. Chem. Soc. 26, 3002 (1974)

(7) G.M. Coppola, Synthesis, 505 (1980)

(8) G.M. Coppola, J. Heterocyclic Chem. 20, 1217 (1983)

(9) G.M. Coppola, J. Heterocyclic Chem. 12, 727 (1982)

(10) C.A. Demerson, L.G. Humbler and A.H. Philipp, J. Med. Chem. 19, 391 (1976)

(11) B.R. Baker, J.P. Joseph, R.E. Schaub, F.J. McEvoy and J.H. Williams, J. Org. Chem. 1Z, 157 (1952)

(12) Physical Data: All ${ }^{1} \mathrm{H}-\mathrm{NMR}$ 's were run in $\mathrm{CDCl}_{3}$ (300 MHz); 8b, mp 96-101 ${ }^{\circ} \mathrm{C},{ }^{1} \mathrm{H}-\mathrm{NMR} \delta 9.34$ (s, broad, $1 \mathrm{H}), 8.14(\mathrm{~d}, 1 \mathrm{H}), 7.72(\mathrm{~d}, 1 \mathrm{H}), 7.33(\mathrm{~m}, 1 \mathrm{H}), 3.22(\mathrm{~m}, 1 \mathrm{H}), 1.40(\mathrm{~d}, 6 \mathrm{H}) .8 \mathrm{~d}, \mathrm{mp} 249-251^{\circ} \mathrm{C},{ }^{1} \mathrm{H}-\mathrm{NMR} \delta$ $10.88\left(\mathrm{~s}\right.$, broad, 1H), $7.86(\mathrm{~d}, 1 \mathrm{H}), 7.22(\mathrm{~d}, 1 \mathrm{H}), 2.46(\mathrm{~s}, 3 \mathrm{H}) .9 \mathrm{a},{ }^{1} \mathrm{H}-\mathrm{NMR} \delta$ 7.16-7.04 (m, 2H), 6.72-6.61 $(\mathrm{m}, 2 \mathrm{H}), 4.66(\mathrm{~s}$, broad, $2 \mathrm{H}), 1.68(\mathrm{~s}, 6 \mathrm{H}) .2 \mathrm{~b},{ }^{1} \mathrm{H}-\mathrm{NMR} \delta 7.13-7.02(\mathrm{~m}, 2 \mathrm{H}), 6.69(\mathrm{t}, 1 \mathrm{H}), 2.95(\mathrm{~m}, 1 \mathrm{H})$, $1.70(\mathrm{~s}, 6 \mathrm{H}), 1.27$ (d, 6H). 2c, ${ }^{1} \mathrm{H}-\mathrm{NMR} \delta 7.01(\mathrm{~d}, 1 \mathrm{H}), 6.61(\mathrm{~m}, 2 \mathrm{H}), 1.64(\mathrm{~s}, 6 \mathrm{H}) .2 \mathrm{~d},{ }^{1} \mathrm{H}-\mathrm{NMR} \delta 6.94(\mathrm{~d}$, 1H), $6.72(\mathrm{~d}, 1 \mathrm{H}), 4.94(\mathrm{~s}$, broad, $2 \mathrm{H}), 2.23(\mathrm{~s}, 3 \mathrm{H}), 1.77\left(\mathrm{~s}\right.$, broad, 1H), $1.67(\mathrm{~s}, 6 \mathrm{H}) .10 \mathrm{a},{ }^{1} \mathrm{H}-\mathrm{NMR} \delta 7.02$ $(\mathrm{m}, 2 \mathrm{H}), 6.71(\mathrm{~m}, 2 \mathrm{H}), 5.30(\mathrm{~m}, 1 \mathrm{H}), 5.03(\mathrm{~m}, 1 \mathrm{H}), 3.86(\mathrm{~s}$, broad, $2 \mathrm{H}), 2.08(\mathrm{~s}, 3 \mathrm{H}) .10 \mathrm{~h},{ }^{1} \mathrm{H}-\mathrm{NMR} \delta 7.08$ (d, $1 \mathrm{H}), 6.89(\mathrm{~d}, 1 \mathrm{H}), 6.75(\mathrm{t}, 1 \mathrm{H}), 5.31(\mathrm{~m}, 1 \mathrm{H}), 5.03(\mathrm{~m}, 1 \mathrm{H}), 3.88(\mathrm{~s}$, broad, $2 \mathrm{H}), 2.92(\mathrm{~m}, 1 \mathrm{H}), 2.08(\mathrm{~s}$, 3H), $1.27(\mathrm{~d}, 6 \mathrm{H}) .10 \mathrm{c},{ }^{1} \mathrm{H}-\mathrm{NMR} \delta 6.95(\mathrm{~d}, 1 \mathrm{H}), 6.70(\mathrm{~m}, 2 \mathrm{H}), 5.32(\mathrm{~m}, 1 \mathrm{H}), 5.05(\mathrm{~m}, 1 \mathrm{H}), 3.92(\mathrm{~s}$, broad, 2H), $2.02(\mathrm{~s}, 3 \mathrm{H}) .10 \mathrm{~d},{ }^{1} \mathrm{H}-\mathrm{NMR} \delta 6.79(\mathrm{~m}, 2 \mathrm{H}), 5.30(\mathrm{~m}, 1 \mathrm{H}), 5.02(\mathrm{~m}, 1 \mathrm{H}), 3.88(\mathrm{~s}$, broad, $2 \mathrm{H}), 2.22(\mathrm{~s}$, 3H), $2.03(\mathrm{~s}, 3 \mathrm{H}) .1 \mathrm{la},{ }^{1} \mathrm{H}-\mathrm{NMR} \delta 7.16(\mathrm{~d}, 1 \mathrm{H}), 7.02(\mathrm{~m}, 1 \mathrm{H}), 6.80(\mathrm{~m}, 1 \mathrm{H}), 6.68(\mathrm{~d}, 1 \mathrm{H}), 3.64$ (s, broad, 2H), $2.92(\mathrm{~m}, 1 \mathrm{H}), 1.26(\mathrm{~d}, 6 \mathrm{H}) .1 \mathrm{~b},{ }^{1} \mathrm{H}-\mathrm{NMR} \delta 7.02(\mathrm{~d}, 2 \mathrm{H}), 6.79(\mathrm{t}, 1 \mathrm{H}), 3.71$ (s, broad, 2H), $2.94(\mathrm{~m}$, 2H), $1.25(\mathrm{~d}, 12 \mathrm{H}) .11 \mathrm{c},{ }^{1} \mathrm{H}-\mathrm{NMR} \delta 7.06(\mathrm{~d}, 1 \mathrm{H}), 6.75(\mathrm{~m}, 1 \mathrm{H}), 6.67(\mathrm{~m}, 1 \mathrm{H}), 3.71(\mathrm{~s}$, broad, $2 \mathrm{H}), 2.84(\mathrm{~m}$, 1H), $1.26(\mathrm{~d}, 6 \mathrm{H}) .11 \mathrm{~d},{ }^{1} \mathrm{H}-\mathrm{NMR} \delta 6.95(\mathrm{~d}, 1 \mathrm{H}), 6.84(\mathrm{~d}, 1 \mathrm{H}), 4.38(\mathrm{~s}$, broad, $2 \mathrm{H}), 2.90(\mathrm{~m}, 1 \mathrm{H}), 2.30(\mathrm{~s}$, 6H), 1.26 (d, 6H). 13a, IR (neat) $1641 \mathrm{~cm}^{-1}$. ${ }^{1} \mathrm{H}-\mathrm{NMR} 87.24-7.04(\mathrm{~m}, 4 \mathrm{H}), 2.09(\mathrm{~s}, 3 \mathrm{H}), 1.61(\mathrm{~s}, 6 \mathrm{H})$.

(13) T.L. Jacobs, S. Winstein, R.B. Henderson and E.C. Spaeth, J. Am. Chem. Soc. 68, 1310 (1946)

Received April 20, 1996 